\title{
PEMBERDAYAAN EKONOMI KREATIF BERBASIS SYARIAH PADA MAJELIS TAKLIM
}

\author{
Khadijah \\ UIN Syarif Hidayatullah Jakarta, Indonesia \\ Email: khadijahmunir@yahoo.co.id
}

\begin{abstract}
Sharia-based economic trends (islamic economics) continue to experience significant progress along with government policies that continue to strive so that the sharia economy can be applied in various aspects of life, including to move the progress of the majelis taklim. Sharia-based economy builds justice because the rich must provide assistance to the poor so that the poor become empowered one of the principles of sharia economic lending without interest. There are at least more than 20 types of regulations concerning the Islamic economic system in Indonesia include the Law of the Republic of Indonesia No. 19, 2008 Regarding State Sharia Securities, and the Law of the Republic of Indonesia No. 21, 2008 about Islamic Banking.
\end{abstract}

Keyword: Creative economy; islamic economics; economic empowerment;

Abstrak. Trend ekonomi Islam (ekonomi syariah) terus mengalami kemajuan yang signifikan seiring dengan kebijakan pemerintah yang terus mengupayakan agar ekonomi tersebut dapat diterapkan di berbagai segi kehidupan, termasuk di dalamnya untuk menggerakan kemajuan Majelis Taklim (MT). Keberadaan MT telah memiliki aturan resmi pemerintah berdasarkan Undang Undang Sistem Pendidikan Nasional (UU Sisdiknas) Nomor: 20 tahun 2003 dan Peraturan Pemerintah (PP). 55 tahun 2007 serta Peraturan Menteri Agama (PMA) No. 29 tahun 2019. Jumlah riil MT di Indonesia diyakini mencapai ratusan ribu tempat mengingat di setiap ada komunitas muslim di situ muncul kegiatan MT. Mereka memerlukan sosialisasi tentang ekonomi syariah sekaligus memberdayakan mereka dengan program yang menggerakan ekonomi kreatif. Pelaksanaan ekonomi syariah mengacu kepada Undang-Undang No. 19 Th. 2008 tentang Surat Berharga Syariah Negara, Undang-Undang Rl No. 21 Tahun 2008 dan Perbankan Syariah setidaknya berjumlah 23 aturan.

Kata Kunci: Ekonomi kreatif; ekonomi syariah; pemberdayaan ekonomi 



\section{Pendahuluan}

Sejak tahun 1980-an dakwah Islamiyah tampak begitu semarak. Jumlah masjid bertambah, jumlah calon jamaah haji meningkat, jumlah zakat/infaq/sadaqah menaik, banyak lembaga pendidikan didirikan termasuk perkembangnan munculnya majelis taklim di mana di setiap komunitas muslim di situ muncul majelis taklim. Pesantren pesantren baru berdiri di mana-mana. Para ustadz, kiai, dan da'i mampu menembus berbagai sektor kehidupan masyarakat. Bahkan dunia artispun sanggup dirambah. Dari kalangan artis sendiri, lahir penyeru-penyeru Islam yang andal. Gaung Islam tak hanya terbatas di masjid-masjid dan madrasah saja, tetapi juga di stasiun-stasiun Televisi dan radio, di kantor-kator, di hotel- hotel berbintang, media cetak, bahkan di "lautan" on-line, internet. Kelompok-kelompok Islam dengan identitas yang lebih fleksibel -baik yang tradisional maupun yang menamakan dirinya modernis hadir secara online. Semangat keislamanpun menyala di mana-mana. (Yunan, 2000). Namun angkaangka kuantitatif tersebut seakan-akan tidak ada artinya, ketika diterpa "badai" Pandemi covid-19 yang membawa kepada krisis moneter yang pada gilirannya juga mengungkap berbagai keterbatasan kita sebagai manusia dan sebagai bangsa. Apa yang dikerjakan selama ini menjadi melemah termasuk kegiatan ekonomi. Pandemi covid-19 atau Corona Virus Disease 2019 (Covid-19) yang telah mengakibatkan memburuknya situasi ekonomi di seluruh dunia, tidak terkecuali situasi ekonomi Indonesia yang antara lain ditandai dengan meluasnya Pemutusan Hubungan Kerja (PHK), kinerja impor yang menurun, terjadinya inflasi, pembatalan penerbangan domestik dan internasional, menurunnya jumlah wisatawan mancanegara (wisman) dan wisatawan domestik (wisdom), penurunan okupansi hotel bagi seluruh lapisan masyarakat. Terlebih lebih setelah diberlakukannya Pembatasan Sosial Berskala Besar (PSBB) di berbagai daerah di Indonesia. Intinya Covid-19 telah memaksa banyak pihak untuk berkreasi di bidang ekonomi kalau mereka ingin tetap eksis secara finasial.

Beberapa Provinsi di Indonesia memberlakukan PSBB termasuk Pemerintah Provinsi DKI Jakarta dengan Peraturan Gubernur Nomor 33 Tahun 2020. Laporan Badan Pusat Statistik (BPS) Agustus 2020 menyebutkan bahwa pertumbuhan ekonomi Indonesia pada kuartal II minus 5,32 persen. Sebelumnya, pada kuartal I 2020 ekonomi Indonesia hanya tumbuh sebesar 2,97 persen, turun jauh dari pertumbuhan sebesar 5,02 persen pada periode yang sama 2019. Kinerja ekonomi yang melemah ini turut pula berdampak pada situasi ketenagakerjaan di Indonesia. (bttps:// wmw.kompas.com/tren/read/2020/08/11/102500165/pandemi-covid-19-apa-saja- dampak-pada-sek.torketenagakerjaan- indonesia, akses 23 Oktober 2020)

Yang perlu disadari, dampak pandemi Covid-19 menghantam semua sektor aktivitas kehidupan masyarakat termasuk di antaranya kegiatan keagamaan (baca: Islam) seperti pengajian-pengajian baik majelis taklim, pendidikan baca Alquran dan juga khutbah- khutbah pada Shalat Jumat. Hal ini disampaikan Wakil Ketua Bidang Komunikasi Politik DPD PDI Perjuangan Sumut, Dr. Aswan Jaya kepada awak media pada Senin (20/4/2020).

"Himbauan pemerintah dan MUI yang menghentikan sementara berbagai kegiatan keagamaan yang mengumpulkan orang banyak seperti shalat berjemaah, pengajian- pengajian dan lain sebagainya tentu berdampak pada berbentinya penghasilan para ustadz/ ab dan guru-guru ngaji." (Aswan, 20/24/20)

Aswan menjelaskan bahwa banyak sekali para ustadz dan guru-guru ngaji yang mengabdikan hidupnya pada kegiatan dakwah dan tidak melakukan berbagai kegiatan lain terutama kegiatan ekonomi. 
Penghasilan mereka untuk menghidupi keluarganya sangat tergantung pada honor saat memberikan pengajian-pengajian dan khutbah-khutbah di Masjid-masjid maupun di majelis-majelis taklim.

"Wabah pandemi covid19 sampai Saat ini menghinggapi selurub lapisan masyarakat tidak terkecuali pejabat walaupun kegiatan pengajian-pengajian dan majelis-majelis taklim mulai lagi dilaksanakan oleh masyarakat, juga sudah banyak Masjid-Masjid yang mulai kembali lagi menyelenggarakan Shalat Jumat berjemaah, namun para ustad dan guru ngaji belum pulih seperti semula dan mereka masi memiliki kendala dalam mendapatkan penghasilan untuk menghidupi keluarganya." (Aswan, 20/24/20)

Untuk menyikapi hal tersebut, Aswan menghimbau kepada pemerintah dan anggota masyarakat memperhatikan nasib para ustadz dan guru ngaji dan menyisihkan rezeki untuk meringankan beban para juru dakwah tersebut. (https://arusmalaka.com/pandemi-covid-19- ustadz-dan-guru-mengajikehilangan- penghasilan, diakses 23 Oktober 2020) pemerintah melalui kementrian Sosial (KEMENSOS) telah banyak berbuat untuk membantu masyarakat yg terdampa covid19 termasuk di dalamnya untuk para ustadz/ustadzah pada majlis taklim missal nya majlis taklim di bawah naungan pergerakan majelis taklim (PERMATA) Indonesia pada 02 November 2020 telah mendapat paket sembako sejumlah 6340 paket yg di salurkan terutama untuk para ustadz/ustadzah dan jamaah nya di lima wilayah kota DKI Jakarta tersebar juga di daerah Bekasi, Depok, Tanggerang selatan/ ciputat. Semoga wabah pandemi segera berlalu sehingga masyarakat kembali hidup normal.

\section{Metodologi Penelitian}

Penelitian ini masuk dalam jenis penelitian kualitatif suatu penelitian yang temuannya tidak diperoleh melalui prosedur statistik. Sumber utama penelitian ini adalah studi kepustakaan yang mengacu kepada literature ekonomi syariah dan buku ekonomi lainnya, buku tentang Majelis Taklim serta karya-karya ilmiah dan dokumen-dokumen tertulis lainnya.

Dalam penelitian kualitatif proses pengumpulan data dan analisa data terjalin sirkulasi berbagai anasir. Mile dan Huberman menggambarkan sirkulasi terjadi antara pengumpulan data, penyajian data, reduksi data dan kesimpulan-kesimpulan. Semua dilakukan dalam proses yang tidak terpisah (Mile dan Huberman, 1992). Dalam penelitian kualitatif ini prosedur sampling yang terpenting adalah menemukan informasi kunci (key informant) atau situasi sosial tertentu yang sarat informasi sesuai dengan fokus penelitian. Sedangkan tehnik yang dipergunakan dalam mencari informan kunci adalah snowball sampling, diawali dengan pengurus, guru, jama'ah, dan selanjutnya partisan atau masyarakat di luar majelis taklim (Burhan Bungin, 2006).

Penelitian kwalitatif dengan sampling penelitian lapangan ini akan difokuskan pada majelis taklim yaitu: Majelis Taklim Pelita Insani, Gang Gapura V, RT/RW : 15/04, Cakung Barat, Kec. Cakung, Jakarta Timur dengan pertimbangan bahwa majelis taklim tersebut mewakili kelompok majelis taklim secara spesifik sesuai dengan tipologi dakwah dalam masyarakat urban kelas bawah dengan asumsi bahwa majelis taklim tersebut bisa "dipoles" dan direkayasa atau dikondisikan untuk mengikuti perkembangan zaman di tengan kempetisi ekonomi yang sangat ketat dan cepat yang mana ekonomi kreatif menjadi kebutuhan nyata bagi siapa saja yang ingin eksis. Sedangkan sasaran utama adalah Para praktisi Majelis Taklim Pelita Insani. Sebagai data pendukung penulis akan memanfaatkan jamaah dan partisan majelis taklim sesuai kebutuhan. 
Studi ini bertujuan untuk mengidentifikasi masalah ekonomi pada majelis taklim, mengetahui sampai sejauh mana majelis taklim memiliki gagasan dan aksi yang dapat mendorong terwujudnya ekonomi kreatif. Asumsi ini didasarkan pada pengamatan penulis bahwa banyak potensial ability (kemampuan yang masih tersimpan) dimiliki komunitas majelis taklim yang punya nilai komersial di bidang seni dan budaya Islami, home industri kerajinan tangan, makanan dan fashion, wisata religi dan lain sebagainya, tapi semua itu belum menjadi actual ability (kemampuan riil yang membuat)

\section{Majelis Taklim Pelita Insani}

Majelis Taklim Pelita Insani merupakan lembaga majelis taklim yang saat berada di bawah Yayasan Pelita Insani yang didirikan pada tahun 2004. Majelis Taklim ini menurut penelitian penulis berawal dari kegiatan dakwah berupa pengajian untuk menjalankan pengajaran agama yang disyi'arkan oleh pasangan suami istri Haji Mu'allim dan Hj. Khaironih pada tahun 1960-an. Selain aktif berdakwah yang dipusatkan di rumah tua di bilangan Kecamatan Cakung, Jakarta Timur, Haji Muallim juga seorang ahli hikmah yang hari harinya diisi dengan kegiatan menerima para tamu yang memiliki berbagai tujuan. Ada yang minta air do'a untuk kesembuhan keluarga yang sedang sakit, ada yang minta doa agar dilapangkan rejekinya, ada yang minta doa untuk dimudahkan urusan yang sedang dihadapi dan lain sebagainya. Haji Muallim (Ustadz Bahruddin, 07 September 2020) melihat umat Islam di sekitar rumahnya membutuhkan perubahan cara berpikir, dari pembiaran keadaan ke cara berpikir dan bertindak antisipatif. Hal itu antara lain dibuktikan dengan keberanian beliau mengemukakan gagasan perlunya membuat jalan yang bisa dilalui mobil sebagai akses warga sekitar ke jalan raya di mana saat itu lokasi pemukiman di mana beliau tinggal hanya ada jalan setapak. Maka ketika jalan itu dibuat berdasar kesepakatan warga, Haji Muallim mempimpin sendiri pembuatan jalan tersebut. Aktivitas dakwah Haji Muallim tidak terbatas hanya pada soal ritual dan ubudiah saja, melainkan juga pada ranah perbaikan kehidupan sosial kemasyarakatan. Dapat dibilang untuk ukuran waktu itu dakwah Haji Muallim sudah cukup maju dan berorientasi ke masa depan.

Kini H. Muallim telah dipanggil Allah SWT 23 Desember 2005 dan istri Hj Khoironih meninggal 06 September 2004. Mereka berdua sebagai cikal bakal hadirnya MajelisTaklim Pelita Insani dengan nama saat ini sebagai tindak lanjut majelis taklim yang dirintis oleh mereka sejak tahun 1960-an. Inti ajaran Islam yang disampaikan majelis taklim ini beragama berlandaskan tauhid, kemurnian iman, solidaritas sosial, dan akhlak al-karimah serta dakwah bil hal yang cukup akomodatif dalam melayani masyarakat, tidak kaku dan rigid. Majelis taklim ini tidak menanamkan semangat kebencian atau ujaran yang tidak menyenangkan kepada orang atau lapisan masyarakat tertentu, serta menganggap ajaran agama untuk diamalkan, bukan untuk diperdebatkan, apalagi untuk jadi alasan saling memusuhi sesama kaum muslim. Majelis taklim ini telah berusia puluhan tahun. Setiap Ahad pagi dan selasa malam ratusan ibu ibu berbondong-bondong mendatangi majelis taklim yang terletak di jalan Inspeksi Pengairan ini, Cakung Barat, Kec. Cakung jakarta Timur ini. Para jamaah datang dari kawasan dan sekitarnya.

Secara historis pertama kali majelis taklim ini diberi nama Pelita Insani pada tahun 2004. Pada awalnya hanya berupa kegiatan pengajian sore hari diperuntukkan bagi anak-anak yang pelaksanaannya bertempat di teras rumah dan terkenal dengan pengajian anak. Selanjutnya diadakan juga perayaan maulid yang tidak hanya sekedar mampu meningkatkan kuantitas jumlah anak-anak yang ikut mengaji, 
akan tetapi juga menarik minat masyarakat Cakung dan sekitarnya dari kalangan yang didominasi kaum ibu dan sedikit bapak-bapak untuk mengadakan pengajian sebagaimana pengajian bagi anak. Kaum ibuibu memilih waktu selasa sore dan minggu sore. Seminggu sekali secara rutin mengadakan pengajian, sedangkan kaum bapak-bapak memilih waktu jum'at malam juga tak mau kalah dengan kaum ibu dan anak rutin mengadakan kegiatan pengajian.

Pada tahun 2000-an bersamaan dengan maraknya jamaah pengajian disusunlah kepengurusan kegiatan pengajian dan sekaligus dikukuhkannya dalam suatu wadah yang dinamakan Majelis Taklim Pelita Insani. Majelis Taklim ini hingga tahun 2020 sekarang ini telah semakin berkembang tidak saja melulu hanya mengadakan kegiatan pengajian rutin. Banyak kegiatan-kegiatan yang telah dihasilkan dari Majelis Taklim Pelita Insani ini, seperti Pendidikan Anak Usia Dini (PAUD), Taman Pendidikan AlQur'ana (TPA) Pagi dan sore, Seni Marawis, Qasidah, Peringatan Hari Besar Islan (PHBI), Santunan anak yatim, yatim piatu dan dhu'afa, Pelatihan menjadi Master of Ceremony (MC), Pelatan Pemulasaraan (pengurusan) Jenazah dll. Sedaangkan materi pengajian pada Majelis Taklim ini meliputi Ilmu-ilmu Agama seperti: Tajwid, Fiqih, Tauhid, Terjemah Al Qur'an, Tafsir Hadist, Aqidah Akhlak dan lain- lain.

Sepanjang penelusuran literatur-literatur yang telah dikaji dan wawancara yang dilakukan penulis dengan Pengurus, Dewan Guru dan jamaah Majelis Taklim Pelita insani serta observasi langsung ke objek penelitian belum ditemukan visi dan misi Majelis Taklim ini secara tertulis di masa awal berdirinya, sebagaimana biasanya terdapat dalam buku AD/ART sebuah organisasi modern. Visi-misi Majelis Taklim ini baru lahir setelah berada di bawah Yayasan Pelita Insani. Namaun demikian bukan berarti majelis taklim ini tidak memiliki haluan dalam penyelenggaraan kegiatan pengajian.

"Mewnjudkan Islam dengan akblak yang mulia, Menumbubkan rasa cinta kepada Allah, Rasul dan ciptaanNya, ikblas, sabar dan syukur serta serah diri kepada Allab SWT; Menjadikan Al-Qur'an dan Al-hadits sebagai dasar hukum; Mencari ridha Allah dengan bersunggub-sungguh melayani umat; Mencari persamaan dalam perbedaan dengan mengedepankan persatuan, kesatuan dan persaudaraan sesama umat; Mewnjudkan suatu tatanan agama yang unggul di segala aspek; dan Membangun masyarakat abli sunnah yang hakiki”. (Ustadh Luthfiah, Lc, dan Henny Susanti, 03 September 2020)

Meskipun untuk mengetahui data anggota dan jamaah majelis taklim Pelita Insani belum bisa dilakukan secara online melalui internet, tapi data mereka yang mencapai 200 (dua ratus) orang tersimpan rapi dan sewaktu waktu bisa dilihat secara offline di kantor sekretariatnya. Bangunan majelis taklim ini berdiri di atas lahan berstatus wakaf, seluas kurang lebih 950 meter persegi, dengan luas bangunan sekitar 750 meter persegi, dengan beberapa ruang yang difungsikan sebagai majelis taklim, balai pertemuan dan PAUD dan Taman Kanak-Kanak.

\section{Mengenal Ekonomi Kreatif Berbasis Syariah}

Di antara nilai yang harus dipegangi dan mejadi komitmen setiap muslim adalah Siddiq (jujur), Amanah (dapat dipercaya), Tabligh (menyampaiakan apa yang harus disampaikan) dan Fathanah (secara bahasa berarti cerdas). 1) Siddiq, true to yourself (jujur pada diri sendiri), be honest to others (jujur kepada orang lain), to be honest to God (jujur kepada Tuhan), to peace (memilih jalan damai) (QS Al-Taubat: 119). Bagi seorang pelaku wirausaha sifat ini adalah modal pokok yang sangat penting.

2) Amanah, bisa berarti respected, honorable (layak dihormati karena pikiran, ucapan, sikap dan 
perbuatannya yang konsisten) dan accautabelity (sikap dapat dapat dipercaya). Sifat ini sangat penging terutama dalam membangun relasi dengan customer 3) Tabligh, secara bahasa berarti menyampaikan. Dalam konteks bisnis bisa diartikan communication skills (keahlian berkomunikasi, mampu mengemukakan argumentasi memasatrkan produknya dengan strategi yang tepat.(Q.S. Al-ahzab: 70-71). 4) Fathanah, secara bahasa berarti cerdas, meliputi intelligence; intellectually, emotionally, and especially spiritually (meliputi kecerdasan intelektual, emosional dan spriritual). (Ali Hasan, Manajemen Bisnis Syari'ah, Pustaka Pelajar, Yogyakarta, 2009, hal 276).

Orang yang memiliki sifat fathanah bisa membuat setiap perbuatannya bernilai ibadah (Murtadha Muthahhari, Akblak Suci Nabi Yang Ummi, Bandung, Mizan, 1995, hal 102).

Dengan sifat Fathanah, seseorang memiliki keunggulan yang bermanfaat dalamkompetensi bisnis yang ia lakukan dalam memabangun ekonomi kreatif, yang berupa:

a) Berkreasi dalam melakukan berbagai inovasi untuk menghasilkan sesuatu yang bermanfaat; b) Mencari dan menemukan peluang-peluangbisnis yang baru, prospektif, dan berwawasan masa depan, sekaligus siap menghadapi dan menanggung berbagai macam resiko; c) Menerjemahkan nila-nilai bisnis dan manajemen yang bertanggung jawab, transparan, disiplin, sadar produksi dan jasa, serta belajar secara berkelanjutan untuk membangun manajemen bisnis yang bervisi islam; d) Melakukan koordinasi, membuat deskripsi tugas, delegasi wewenang, membentuk kerja tim, responsif, mampu membuat sistem pengendalian dan melakukan supervisi yang baik; e) Berkompetisi dengan sehat, mendeteksi kelemahan, membuat ancangan antisipasi, ancangan pertumbuhan bisnis dan ancangan mengawal bisnisnya.

\section{Ekonomi Konvensional}

Saat ini ada dua sistem perekonomian yang berjalan ekonomi konvensional dan ekonomi Islam/Ekonomi Syariah. Ekonomi konvensional merupakan sebuah sistem di mana terdapat aktivitas manusia untuk melakukan kegiatan produksi, distribusi, pertukaran dan perolehan serta komsumsi baik berupa barang ataupun jasa. Ekonomi ini berpacu kepada fenomena duniawi yang menafikan Tuhan. (Muzeyein, 2019).

Sistem ekonomi konvensional yang sering disebut juga dengan ekonomi kapitalis seperti berlaku di Eropa dan Amerika berpegang pada hukum pasar. Kapitalisme adalah sistem ekonomi di mana perdagangan, industri dan alat-alat produksi dikendalikan oleh pemilik swasta dengan tujuan memperoleh keuntungan dalam ekonomi pasar. (Oxford Dictionaries, 2013). Chris Jenks dalam Core Sociological Dichotomies mendefinisikan Capitalism as a mode of production, is an economic system of manufacture and exchange which is geared toward the production and sale of commodities within a market for profit, where the manufacture of commodities consists of the use of the formally free labor of workers in exchange for a wage to create commodities in which the manufacturer extracts surplus value from the labor of the workers in terms of the difference between the wages paid to the worker and the value of the commodity produced by him/her to generate that profit." (Chris Jenks). Arti dari paragrap diatas "Kapitalisme sebagai mode produksi, adalah sistem ekonomi produksi (pabrikan) dan pertukaran (barang dan jasa) yang diarahkan pada produksi dan penjualan komoditas di pasar dalam rangka mendapatkan keuntungan, di mana produksi komoditas terdiri dari penggunaan tenaga kerja 
resmi dengan imbalan upah untuk menciptakan komoditas di mana pabrikan mengeksploitasi tenaga pekerja dalam hal perbedaan antara upah yang dibayarkan kepada pekerja dan nilai komoditas yang diproduksi olehnya untuk menghasilkan keuntungan itu." (Chris Jenks).

Pertentangan antara buruh dan pemilik modal bukan dikarenakan para buruh iri atau para majikan egois, melainkan karena kepentingan dua kelas itu secara objektif berlawanan satu sama lain. Franz Magnis Suseno (2010).

Karakteristik umum kapitalisme antara lain: a menganggap ekspansi kekayaan yang dipercepat dan produksi yangmaksimal serta pemenuhan keinginan menurut preferensi individual sebagaisesuatu yang esensial bagi kesejahteraan manusia. b) menganggap bahwa kebebasan individu yang tak terhambat dalam mengaktualisasikan kepentingan diri sendiri dan kepemilikan atau pengelolaan kekayaan pribadi sebagai suatu hal yang sangat penting bagi inisiatif individu. c) berasumsi bahwa inisiatif individu ditambah dengan pembuatan keputusan yang terdesentralisasi dalam suatu pasar yang kompetitif sebagai syaratutama untuk mewujudkan efisiensi optimum dalam alokasi sumber daya ekonomi. d) idak menyukai pentingnya peranan pemerintah atau penilaian kolektif (oleh masyarakat), baik dalam efisiensi alokatif maupun pemerataan distributif. e) Kapitalisme mengklaim bahwa melayani kepentingan diri sendiri oleh setiap individu secara otomatis akan melayani kepentingan sosial kolektif.

\section{Ekonomi Syariah}

Sistem ekonomi syariah sistem ekonomi yang diilhami oleh nilai-nilai Islam. Ekonomi syariah merupakan ekonomi Rabbaniyah, Ilahiyah yang didasarkan dan dijiwai oleh hukum dan nilai ketuhanan. Nilai tersebut secara otomatis berefek kepada nilai Insaniyah yaitu nilai yang menjunjung tinggi kemanusiaan, di mana antar sesama manusia tidak saling memangsa, jika pun ada kompetitisi maka dilakukan dengan sehat. Sesuai dengan petunjuk alquran فَانْنَقُقُ ا الْخَبْرَاتِ berlomba-lombalah dalam kebaikan (QS. Al-Baqarah: 148). Itu sebabnya sistem ekonomi ini disebut ekonomi berakhlak karena mendasarkan pada bangunan etika.

Ekonomi syariah masih relatif baru, maka perlu disosialisasikan di tengah masyarakat termasuk di dalamnya kepada kelompok majelis taklim. Dakwah pada majelis taklim sebagai lembaga /organisasi Islam memiliki program luas (konphrehensip), karena meliputi masalah duniawi dan ukhrawi secara

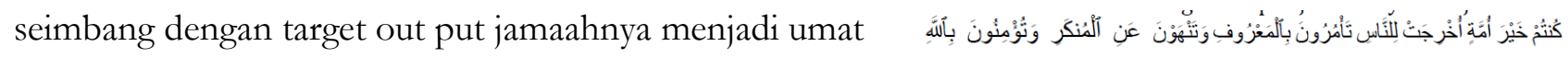

"Kamu adalab umat yang terbaik yang dilabirkan untuk manusia, menyurub kepada yang ma'ruf, dan mencegab dari yang munkar, dan beriman kepada Allab" (Q.S. Ali-imran :110). Menurut tafsir Al-madinah Al-munawarah umat terbaik adalah menjadi umat yang bermanfaat hidupnya, sedang Al-maraghi menafsirkan orangorang yang lemah di antara mereka tidak takut terhadap orang-orang yang kuat dan yang kecilpun tidak takut kepada yang besar. Sebab, iman telah meresap ke dalam kalbu dan perasaan mereka (al-maraghi, 1986). Kemampuan majelis taklim untuk menjadikan jamaah serta majelis taklimnya berkualitas sangat mungkin terjadi jika dibantu dengan program unit usaha yang mencakup ekonomi kreatif berbasis syariah. Filosofi sistem ekonomi kapitalis adalah materialisme dan sekularisme. Pengertian manusia sebagai homo economicus atau economic man adalah manusia yang materialis hedonis, sehingga ia selalu dianggap memiliki serakah atau rakus terhadap materi. Ekonomi konvensional mengabaikan moral dan etika dalam pembelanjaan dan unsur waktu adalah terbatas hanya di dunia saja tanpa mengambil akhirat. 
Sistem ekonomi syariah telah menjadi bagian terpenting dan strategis sebagai salah satu mtotor penggerak roda perekonomian Indonesia. (Kusmanto, 2014/12/14). Stresing ekonomi Islam dekatnya dengan sektor riil yaitu konsep ekonomi dan keuangan Islam, seperti Usaha Mikro Kecil dan Menengah (UMKM) maupun industri rumahan yang bergerak di bidang makanan, kerajinan, serta jasadan sektor keuangan. Sektor keuangan mencerminkan keadaan yang sesungguh-nya dari sektor riil, dan ia pula dapat menjadi penggerak sektor riil. Pada sisi lain minat masyarakat untuk mempelajari sistem ekonomi syariah semakin meningkat. (Antonio, 2001).

Secara formal lahirnya ekonomi syariah di Indonesia ditandai dengan berdirinya lembagalembaga keuangan syariah yang mendasarkan prinsip bagi hasil atau profit and loss sharing (Fitria, 2016). Perkembangan Ekonomi Syariah di Indonesia diawali dengan lahirnya Perbankan Syariah. (Kelik Pramudya, 2018). Program ini mendapatkan momentumnya semenjak didirikannya Bank Muamalat pada tahun 1992. Pendirian bank ini didasarkan pada Undang-Undang Nomor 7 Tahun 1992 sebagai landasan hukum bank kemudian disempurnakan dengan Undang-undang Nomor 10 Tahun 1998 tentang Perubahan atas Undang-undang Nomor 7 Tahun 1992 tentang Perbankan.

Dalam sistem ekonomi syariah tidak ada eksploitasi tenaga manusia oleh manusia lain dan baik individu maupun kelompok dan pekerja maupun pemodal memiliki ruang untuk mengelola harta kekayaan. Sedangkan negara memiliki peran mengarahkan dan membuat regulasinya agar tidak ada pihak pihak yang dirugikan. Semua itu dimaksudkan agar produksi, konsumsi, sirkulasi dan distribusi tidak beredar hanya pada segelintir orang atau kelompok tertentu saja. (Q.S. Al-Hasyr:7).

Menurut Islam, pengelolaan, sirkulasi dan distribusi harta yang dimiliki umat Islam ada dua model, 1) model yang berorientasi profit 2) model yang berorientasi non profit. Model yang berorientasi profit dalam kitab fiqh klasik dibahas pada bab mu'amalah, pembahasannya antara lain meliputi transaksi jual beli (ba'i), leasing (hiwalah), kerjasama (musyarakah) hutang piutang (dayn), gadai (Rahn), jual beli dengan order (salam) dan sebaginya. Sedang model yang berorientasi non profit meliputi pengeloaan zakat, sadaqah, infak, dan wakaf. Potensinya sangat besar, jika terkoordinasi dengan baik, menurut riset Badan Amil Zakat Nasional (BAZNAS) dan Fakultas Ekonomi Manajemen (FEM) Institut Pertanian Bogor (IPB) tabun 2011 mencapai angka 3,4 persen dari total Produk. Domestik. Bruto (PDB) atau kurang lebib Rp 217 triliun. Khusus potensi zakat dari Giro Wadiah dan Deposito Mudharabah di perbankan syariah, ditemukan bahwa potensi zakat keduanya mencapai masing-masing sebesar $\mathrm{R} p 155$ miliar dan $\mathrm{R} p 739$ miliar. (bttp:/ / wmw.baznas.or.id/ib-peduli).

Pengelolaan harta non profit dikemukakan juga dalam tulisan ini, mengingat penggunaan zakat, infak, sadaqah dan bahkan harta wakaf apabila sesuai dengan peruntukannya dapat dijadikan sebagai salah satu instrumen untuk mengangkat penghasilan kelompok ekonomi lemah dengan catatan ditasarrufkan untuk hal produktif, bukan konsumtif, misalanya digunakan sebagai modal awal pengelolaan kegiatan ekonomi mereka yang profit oriented (berorientasi profit).

Membahas ekonomi majelis taklim atau lebih tepatnya membahas Pemberdayaan Ekonomi Kreatif Berbasis Syariah Pada Majelis Taklim diperlukan membahas sistem ekonomi pedesaan sebab mayoritas majelis taklim berada di pedesaan. Berdasarkan data dari Kementerian Agama RI, sampai dengan saat ini setidaknya ada 48981 majelis taklim di seluruh wilayah negeri ini 
(http://simpenais.kemenag.go.id/majelis dan https://bdkpalembang.com/ekonomi-kreatif-berbasismajelis-taklim-sebagai-solusi-meningkatkan-konomi-umat, diakses 24 April 2020).

Sementara itu sistem ekonomi perdesaan di Indonesia dalam konteks kekinian sedang berlangsung pergumulan sistem ekonomi tradisional (pra-kapitalistik) dengan ekonomi modern (kapitalistik). Sistem ekonomi kapitalistik di perdesaan merupakan bentuk penetrasi perkotaan atas perdesaan. Mentalitas ekonomi kota telah menjungkir balikan prinsip- prinsip ekonomi produksi masyarakat perdesaan.

Selama ini proses produksi ekonomi perdesaan dilakukan untuk swasembada, dengan sedikit kelebihan yang dijual ke pasar. Mentalitas kota telah merubahnya menjadi hukum pertukaran sebagai dasar proses produksi. Petani tumbub menjadi wiraswasta, berproduksi untuk usaha- usaha perdagangan. (J.H. Boeke, 1983).

\section{Ekonomi Kreatif}

Konsep Ekonomi Kreatif adalah konsep ekonomi yang mengandalkan informasi dan kreativitas di mana ide dan kesiapan ilmu (stock of knowledge) dari Sumber Daya Manusia (SDM) merupakan faktor utama dalam kegiatan ekonomi. (Afifi, 2012). Secara sederhana, ekonomi kreatif dapat didefinisikan dengan bagaimana cara orang menghasilkan uang melalui ide atau gagasan (Howkins J, 2001). Cara ini mencakup produksi barang dan jasa, transaksi yang terkait dan pendukung lainnya. Berdasarkan data nasional, sektor industri kreatif telah menyerap 15,9 juta tenaga kerja dengan kontribusi 7,3 persen terhadap produk domestik bruto maupun juga setara dengan Rp 852 triliun. Pada skala global, nilai ekonomi industri kreatif bahkan mampu melampaui industri perminyakan. Berdasarkan data yang telah dikeluarkan oleh Konferensi Perdagangan dan juga Pembangunan Perserikatan Bangsa- Bangsa (UNCTAD) pada tahun 2012, industri kreatif ini akan menyumbang USD 2,2 triliun atau 230 persen lebih banyak dari nilai ekspor minyak OPEC. Industri budaya dan juga kreatif termasuk sektor ekonomi yang paling inovatif. (https://pengajar.co.id/ekonomi-kreatif- adalah, diakses 8 Mei 2020).

Ekonomi kreatif bertumpu pada gagasan baru dan orisinil, sedamgkan ide dan desain baru pada industri budaya tradisional cenderung mengutamakan preservasi nilai dan warisan budaya daerah yang memberikan nilai jual yang unik. (Kong dkk., 2006, O’Connor \& Xin, 2006). Kegiatan ekonomi berbasis kreativitas pada masyarakat dunia (tak terkecuali masyarakat Indonesia-pen) sudah berlangsung sejak lama, namun pada umumnya semua itu terbatas pada kerajinan tangan belaka. (UNESCO dan UNDP, 2013), misalnya di bidang pembuatan makanan, pakaian, perhiasan dan asesoris. Pada era digital seperti sekarang ini, kegiatan ekonomi berbasis kreatifitas berkembang pesat, bukan saja bertumpu pada kerajinan tangan, tapi pada ide dan gagasan yang bisa dijual dan menghasilkan uang berlimpah.

Berdasarkan Inpres Nomor 6 Tahun 2009, ruang lingkup ekonomi kreatif di Indonesia adalah sebagai berikut: a) Periklanan (advertising); b) Arsitektur (desain bangunan secara menyeluruh; c) Pasar barang seni (perdagangan barang-barang asli, unik dan langka serta memiliki nilai estetika seni dan sejarah yang tinggi); d) Kerajinan (craft) yaitu kegiatan kreatif yang dibuat atau dihasilkan oleh tenaga pengrajin yang berawal dari desain awal sampai proses penyelesaian produknya; e) Desain, meliputi kreatifitas di bidang desain grafis, desain interior, desain produk, desain industri, konsultasi identitas perusahaan dan jasa riset pemasaran serta produksi kemasan dan jasa pengepakan; f) Fesyen (fashion) meliputi kreatifitas di bidang desain pakaian, desain alas kaki, dan desain aksesoris mode lainnya, produksi pakaian mode dan aksesorisnya, konsultasi lini produk berikut distribusi produk fesyen; g) 
Video, Film dan Fotografi; produksi video, film, dan jasa fotografi, serta distribusi rekaman video dan film. Termasuk di dalamnya penulisan skrip, dubbing film, sinematografi, sinetron, dan eksibisi atau festival film; h) Permainan Interaktif (game); namun yang perli diingat, sub-sektor permainan interaktif harus menjadi alat bantu pembelajaran atau edukasi; i) Musik; meliputi kreatifitas mengenai komposisi, pertunjukkan, reproduksi, dan distribusi dari rekaman suara; j) Seni Pertunjukkan (showbiz); k) Penerbitan dan Percetakan; l) Layanan Komputer dan Piranti Lunak (software); Televisi \& Radio (broadcasting); m) Riset dan Pengembangan (R\&D). (Lihat, Prof.Dr.Faisal Afiff, Se.Spec.Lic, Pilar-Pilar Ekonomi Kreatif, 2012).

Perusahaan juga harus mampu meng- internalisasi eksternalitas dan pengetahuan yang tersedia di sekitarnya, sehingga hal ini dapat bermanfaat dalam pengembangan bisnisnya (Qian \& Acs, 2013, Smit dkk., 2015; Westlund, 2006).

\section{Potensi Majelis Taklim Di Bidang Ekonomi Kreatif}

Majelis taklim dengan jumlah sebanyak 48.981 (empat puluh delapan ribu embilan ratus delapan puluh satu) buah sebagaimana disebutkan yang tersebar di seluruh penjuru tanah air, pada dasarnya memiliki potensi yang signifikan dan kedudukan cukup strategis. Memiliki jamaah mencapai jutaan orang berarti majelis taklim bisa memiliki andil besar terhadap maju mundurnya bangsa Indonesia. Jika majelis taklim maju, secara otomatis banyak warga bangsa yang mengalami kesejahtraan. Memajukan anggota majelis taklim juga boleh dimaknai memajukan sebagaian warga pedesaan karena sebagian besar majelis taklim berada di pedesaan. Peran dan fungsi majelis taklim menjadikan wadah tersebut strategis karena di samping tempat belajar agama (tafaqquh fiddin), majelis taklim juga menjadi pusat pemberdayaan ekonomi umat dan tempat penyebaran informasi (Khadijah, 2014). Dengan demikian keberadaannya yang menyebar ke seluruh penjuru tanah air berarti majelis taklim dapat manjadi pusat perubahan sosial (sosial of changes) menuju tatanan Indonesia maju. Penyebarannya yang menyuluruh di seluruh penjuru tanah air ini sesunguhnya merupakan potensi dan nilai lebih majelis taklim yang selama ini belum tergarap secara maksimal.

Titik lemah majelis taklim yang sulit diatasi, mengingat majelis taklim majelis taklim itu banyak yang tumbuh dari bawah (bottom up), akibatnya sulit diseragamkan dengan satu misi, visi ataupun satu model bahan ajar dan kurikulum. Akibat selanjutnya mejelis taklim jadi sangat veriatif dan berwarna warni. Ada majelis taklim yang berdiri karena kesamaan profesi ataupun hobby anggotanya, ada yang berdiri karena kesamaan tempat tinggal anggotanya sebagaimana majelis taklim di kampung kampung, ada yang berdiri karena kesamaan usia anggotanya. Dan bahkan ada majelis taklim yang berdiri karena kesamaan latar belakang budaya dan daerah anggotanya, misalnya majelis taklim yang didirikan oleh perkumpulan orang-orang perantauan di suatu daerah. Pada titik ini, majelis taklim memiliki dua sisi; kelebihan dan kekurangan yang tidak dimiliki oleh komunitas lain.

Seringkali kegiatan ekonomi pada majelis taklim diletakan pada lingkup kegiatan skunder, musiman, amatir dan sekedar menyalurkan hobby, bukan diletakkan pada lingkup kegiatan primer yang mencontoh acuan industri. Keberadaan majelis taklim selama ini belum memiliki methoda yang sisimatik. Baru pada tahun 2014 hadir teori pola bina sebagia bedah analisis terhadap program majelis taklim. Di mana teori tersebut menjadi guidency untuk menjadikan berjalan efektif efisien sistemik dan maju, karena menjawab kebutuhan riil jamaah. Salah satu aspek penting pada teori tersebut terdapat 
penguatan ekonomi majelis taklim termasuk di dalamnya ekonomi kreatif (Khadijah, 2014). Pola bina tersebut belum menjadi acauan. Akibatnya kegiatan belum menempatkan program pemberdayaan ekonomi kreatif pada skala primer, karenanya majelis taklim belum memiliki nilai tambah secara finansial dan program kerja kurang berorientasi jangka panjang.

Berbeda dengan kegiatan ekonomi yang bersifat industrial; ia memiliki ciri - ciri memproduksi apa yang akan dijual secara massal dengan cepat dan perhitungan yang tepat, melibatkan mesin dan ilmu pengetahuan sesuai yang dibutuhkan, memiliki sasaran pelanggan yang terukur, dan melakukan inovasi produksi secara terus menerus, orientasinya tidak sekedar menumbuhkan potensi ekonomi dari kegiatan kreatif penduduk, namun lebih jauh untuk menggenjot kegiatan kreatif penduduk menjadi suatu industri tersendiri yang kuat dan besar yang mampu meningkatkan kesejeahteraan anggota secara signifikan, nomenklatur industri kreatif (Inpres Nomor: 6 Tahun 2009 tentang Pengembangan Ekonomi Kreatif). Menyamakan program majelis taklim yang notabene lembaga pendidikan non formal dengan kegiatan industri yang berorintasi mencari untung (bisnis) kurang tepat akan tetapi setidaknya majels taklim dapat belajar sebagai komparasi bagaiman meningkatkan produktifitas menjadi sebuah upaya belajar tentang mendatang-kan income finansial untuk membantu para jamaah yang membutuhkan. Karena islam mengajarkan kepada umatnya untuk hidup seimbang dan bahagia duniawi dan ukhrowi dan Allah lebih menyukai hamba yang kuat dibanding dengan hamba yang lemah (alhadist).

\section{Ekonomi Kreatif Pada Majelis Taklim Dan Tantangannya}

Temuan Penulis menunjukkan bahwa masalah yang dihadapi majelis taklim secara umum meliputi; manajemen, sumber daya ustadz dan pengelola dan kemandirian secara finansial. Masalah finasial dan ekonomi jamaah pada majelis taklim menjadi masalah yang menonjol dan dalam. Ini sangat bisa terjadi karena kebanyakan majelis taklim berada di pedesaan, di mana kebanyakan warga miskin di negeri kita tinggal di pedesaan. Namun demikian problem finansial bukan sesuatu yang tidk dapat diatasi. Pemerintah menyalurkan KUR (Kredit Usaha Rakyat) tanpa agunan dengan plafon maksimal Rp 50.000.000,-. Begitu pula Lembaga Non Pemerinah (NGO) banyak bersedia memberi bantuan kepaada majelis taklim ataupun program pendampingan ekonomi dalam bentuk lain.

Menteri Koperasi dan UKM Teten Masduki mengakui masih lambatnya penyerapan KUR lantaran UMKM masih kesulitan mengakses kredit berbunga 6\% ini. Lantaran bank sebagai penyalur KUR harus menjalankan mitigasi risiko yang ketat.

"Untuk KUR mikro dengan plafon $\mathrm{Rp} 50$ juta, itu tanpa agunan. Praktiknya masih dibaruskan pakai agunan, karena bank takut NPL (non performing loan). Kami sudab mengangkat isu ini di rapat kabinet sebelum pandemi Covid-19. Kami carikan bagaimana penyaluran KUR bisa lebih mudah dijangkau oleh usaha mikro dan ultra mikro." Teten dalam webinar, Jumat (12/6) (https://keuangan.kontan.co.id/news/pe nyerapan-kur-masib-rendah-kemenkop- ukm-ingin-libatkan-p2p-lending, diakses 23 Oktober 2020).

Majelis Taklim Pelita Insani ini telah mampu menarik jamaah yang berasal dari masyarakat sekitar terutama dari kalangan ekonomi lemah. Keberadaan majelis taklim ini masih tetap eksis hingga kini. Seperti dipaparkan di atas, majelis taklim ini telah memiliki lembaga pendidikan yang berupa Pendidikan Anak Usia Dini (PAUD), Taman Pendidikan Al-Qur'ana (TPA) Pagi dan sore dan juga mengmebnagkan seni budaya Islam seperti Marawis, Qasidah, Peringatan Hari Besar Islam (PHBI), 
Santunan anak yatim dan dhu'afa, Pelatihan-pelatihan MC, Pelatihan Pemulasaraan Jenazah dan lainlain.

Namun dalam amatan penulis, kegiatan profit yang berupa pemberdayaan ekonomi kreatif baik bagi jamaah maupun bagi institusinya masih mengalami kendala berupa sulitnya meningkatkan animo, minat dan disiplin anggota untuk berwira usaha secara profesional. Hal ini diakui Ketua Pengurusnya, Ustadzah Luthfiah, Lc. (23 Oktober 2020) Menurut pengakuannya, jamaah majelis taklim ini dalam satu tahun mampu mengumpulkan dana hingga sebesar Rp 25.000.000,- (dua puluh lima juta rupiah) untuk membeli sapi yang dipotong pada hari raya iedhul adha dan dagingnya dibagi bagikan ke sesama anggota serta warga sekitar. Tapi giliran merka diminta patungan untuk modal usaha bersama, jangankan Rp. 25.000.000,- diminta patungan untuk pengumpulan dana 2.500.000,- (dua juta limaratus ribu rupiah) saja belum tentu ada yang minat.

Lain Ustadzah Luthfiah, Lc, lain pula Ustadzah Yoyoh Masturoh (15 Oktober 2020) Menurut Ustadzah Yoyoh, sebagian para ibu anggota majelis taklim adalah pedagang kecil yang sudah terbiasa dengan usaha mandiri yang berpikirnya sangat praktis dan jangka pendek. Misalnya jualan nasi uduk yang dimasak pagi hari, lalu dijual paling akhir sampai jam 11.00 wib siang sudah selesai dan keuntungannya bisa dinikmati hari itu juga. Begitu pula yang jualan kue basah, kulak di pagi hari, siang harinya sudah habis terjual. Dengan kata lain mengubah mindset jamaah agar memiliki karakter bisnis yang terorganisir dan profesional masih merupakan hal yang perlu diusahakan dengan penuh keuletan, kesabaran dan berkesinambungan. Ini dapat dimaklumi karena rata rata mereka adalah ibu-ibu yang berusia di atas 50-an, jika pun ada yang usia muda taraf pendidikan mereka rendah maksimal SMA/Aliyah. Sehingga untuk merubah kemapanan berpikir mereka, terutama berpikir dalam hal usaha dengan spesifikasi ekonomi kreatif tidaklah mudah. Akibat lebih jauh, mengajak mereka untuk terlibat secara aktif membangun eknomi kreatif berbasis syariah juga menjadi hal yang tidak mudah, karena membangun ekonomi kreatif meniscayakan adanya kekayaan gagasan dan ide, sedangkan para ibu itu lebih menyukai kemapanan (establishment) yang selama ini mereka jalani. Hal lain yang kenjadi kendala bagi tumbuhnya ekonomi kreatif berbasisi syariah di majelis taklim adalah karena mereka tidak tertarik untuk melakukan usaha tersebut.

Empat nilai ajaran Islam yang kemudian menjadi karakter ibu ibu anggota majelis taklim, yaitu shiddik, amanah, tabligh dan fathanah terrnyata tidak secara otomatis membuat mereka tertarik membangun ekonomi kreatif barbasis syariah, karena untuk menjadi enterprenuer di samping membutuhkan modal finansial, juga membutuhkan modal karakter dan mental pelaku usaha yang kuat. Apalagi dalam hal ekonomi kreatif yang tentu saja memerlukan kecerdasan agar kaya ide dan gagasan yang punya nila jual.

Menurut kesimpulan penulis, melakukan PemberdayaanEkonomi Kreatif Berbasis Syariah Pada Majelis Taklim Pelita Insani sesuatu yang bisa dilakukan, namun masih sangat memerlukan pelatihan dan training yang eksta untuk pembentukan karakter bisnis, karena faktor kemapanan berpikir mereka yang selama ini telah terbentuk dengan karakter berdagang secara tradisional. 


\section{Penutup}

Dilihat dari paradigma dan pola komunikasi dakwah, Majelis Taklim Pelita Insani mengalami kemajuan. Perubahan paradigma tersebut punya tujuan untuk menciptakan dan mewujudkan komponen komunikasi dakwah yang terdiri dari Sender/dai/Komunikator, Message/maddah/materi, Channel/tariqob/media-Recepiennt/mad'u/komunikan-Effect/atsar/dampake (SMCR-E) secara demokratis, tercerahkan, serta emansipatoris dan partisipatif aktif yang tercermin dalam bentuk: Pertama, dalam tataran Sender/ däi Majelis Taklim Pelita Insani memiliki dai/pengajar dengan pola bina sender (dai) yang baik, bersih, berwibawa, dan bertanggungjawab dapat diurai lebih rinci lagi ke dalam lima unsur penting, yaitu: transparency (Siddiq), consistency (Istiqomah), intelligency (Fatonab), accountability (Amanab), dan comunicatibility (Tabligh). Kelima unsur ini selain merupakan sistem da'i Majelis Taklim juga sebagai sikap pribadi seorang juru dakwah. Kedua, dalam tataran pesan (message) Dakwah pada Majelis Taklim Pelita Insani, pesan yang disampaikan dalam dakwahnya kecuali berisi pesan keagamaan dalam arti yang sesuai pokok jaran islam berupa ibadah syari'at, juga perlu ditambah lebih banyak lagi dengan persoalan riil dari apa yang selama ini disampaikan. Kedua, dalam tataran Channel (wasilab/media dakwah), Majelis Taklim Pelita Insani masih menggunakan media dakwah tradisional berupa penyampaian secara oral dalam suatu pertemuan. Keduanya dapat disinergikan dengan menggunakan media dakwah kontemporer. Media Dakwah kontemporer menghendaki dakwah yang dilakukan dengan cara menggunakan teknologi modern yang sedang berkembang dengan menggunakan media teknologi yang sesuai dengan tuntutan zaman, dakwah sudah saatnya harus disampaikan dengan menggunakan metode cepat dan tepat, yaitu dengan cara menggunakan fasilitas teknologi. Keempat, Majelis Taklim Pelita Insani masih cenderung menggunakan pola top down dari pada pola bottom up untuk lebih memandirikan recepien-nya (penerima pesan). Dalam hal ini majelis taklim harus mampu menciptakan kondisi di mana setiap anggota majelis taklim (recipient / mad'u) dan lapisan masyarakat melibatkan diri dalam penyelesaian berbagai persoalan kehidupan yang mereka alami dengan gemar membaca, mempelajari dan mendiskusikan aneka persoalan sosial keagamaan mereka untuk mendapat solusi. Kelima, dalam tataran Effect (atsar) Majelis Taklim Pelita Insani mestinya lebih mensinergikan effek dakwah paradigma baru majelis taklim dalam menghadapi perubahan sosial, yaitu terbentuknya pribadi muslim yang mempunyai iman yang kuat, tertanamnya akidah yang mantap di setiap hati jamah serta memiliki jiwa enterpreneurship. Jika dakwah telah dapat menyentuh aspek-aspek perubahan tersebut pada jamaah dan memiliki kemandirian ekonomi kreatif berbasis syyariah, maka majelis Taklim Pelita Insani sebagai lembaga dakwah dapat dikatakan berhasil dengan baik. Sehingga dapat membentuk masyarakat idal untuk menggapai kepentingan duniawi dan ukhrawi.

\section{Daftar Pustaka}

Afif, Faisal, Pilar-Pilar Ekonomi Kreatif, http://www.feb.unpad.ac.id/id/arsip-fakultas-ekonomiunpad/opini, diakses pada tanggal 12 April 2012.

Ali Hasan, Manajemen Bisnis Syari'ah, Pustaka Pelajar, Yogyakarta, 2009

Burhan Bungin, Analisis Data Penelitian (Jakarta: PT. Raja Grafindo Persada, 2006), 153. 
Chris Jenks, Core Sociological Dichotomies. London, England, UK; Thousand Oaks, California, USA; New Delhi, India: SAGE. hlm. 383.

Franz Magnis Suseno (2010). Pemikiran Karl Marx: Dari Sosialisme Utopis ke Perselisihan Revisionisme. Gramedia Pustaka Utama. hlm. 110-134. ISBN 978-979-655-331-0.)

Howkins J, The Creative Economy: How People make Money from Ideas, London: Penguin Press, 2001

J.H. Boeke, Pra Kapitalisme di Asia, terjemahan D. Projosiswoyo, Penerbit Sinar Harapan, Jakarta, 1983, hlm. $9-10$.

Kong L, Gibson C, Khoo L-M, et al. (2006) Knowledges of the creative economy: Towards a relational geography of diffusion and adaptation in Asia. Asia Pacific Viewpoint, 47(2), 173-194.

Kelik Pramudya, Strategi Pengembangan Ekonomi Syariah Melalui Penguatan Fungsi Pengadilan Agama Dalam Penyelesaian Sengketa, Jurnal Rechtsvinding, Media Pembinaan Hukum Nasional, ISSN 2089-9009, Vol. 7, No. 1 April, 2018

Mile dan Huberman, Analisis Data Kualitatif, Jakarta: UI-Press, 1992

Muhammad Syafi'i Antonio, Bank Syari'ah, Cet. 1, Jakarta: Gema Insani, 2001

Murtadha Muthahhari, Akblak Suci Nabi Yang Ummi, Bandung, Mizan, 1995

Oxford Dictionaries online. "capitalism. an economic and political system in which a country's trade and industry are controlled by private owners for profit, rather than by the state." Dilihat tanggal 4 January 2013.

Qian H dan Acs ZJ (2013) An absorptive capacity theory of knowledge spillover entrepreneurship. Small Business Economics, 40 (2), 185-197.

Tira Nur Fitria, Kontribusi Ekonomi Islam Dalam Pembangunan Ekonomi Nasional, Jurnal Ilmiah Ekonomi Islam, Vol.2, No. 03, 2016Alfarizi, Salman. (2012). Mohammad Hatta: Biografi Singkat 1902-1980. Yogyakarta: Garasi.

UNESCO dan UNDP Creative Economy Report 2013: Special Edition: Widening Local Development Pathways, New York and Paris: UNESCO dan UNDP, 2013

Yusuf Yunan, Masalah Dakwah Agenda Dan Solusi, dalam Muhtadi, Asep S. dan Sri Hadajani (ed). Dakwah Kontemporer, Pola Alternatif Dakwah Melalui Televisi, Pusdai Perss, Bandung, 2000.

https:// arusmalaka.com/pandemi-covid-19-ustadz-dan-guru-mengaji-kebilangan-penghasilan/ (dilihat hari Jum'at, tgl 23 Oktober 2020)

http://www.baznas.or.id/ib-peduli// (dilihat pada Rabu, 26 Juni 2013, jam 16.08).

https://bdkpalembang.com/ekonomi-kreatif-berbasis-majelis-taklim-sebagai-solusi-meningkatkanekonomi-umat/(dilihat pada hari senin, tgl 24 April 2020)

bttps:// wmw.kompas.com/tren/read/2020/08/11/102500165/pandemi-covid-19-apa-saja-dampak-pada-sek.torketenagakerjaan-indonesia-?page =all. (dilihat hari Jum'at, tgl 23 Oktober 2020)

https://republika.co.id/berita/p4suiq313/me mahami-istilah-majelis-taklim (dilihat pada Senin, 13 April 2020, jam 09.01). 
MIMBAR Agama Budaya, 37 (2), 2020

http://simpenais.kemenag.go.id/majelis (dilihat pada hari senin, tgl 24 April 2020)

https://akurat.co/hiburan/id-973164-read-tren-selebritas-hijrah-meningkat-ini-4-kelompok-pengajianartis-terpopuler-di- indonesia (dilihat hari jum'at 23 Oktober 2020). 